\title{
PREDICTING WOOD STRENGTH UPON COMPRESSION ALONG FIBERS
}

\author{
Vladimir Glukhikh ${ }^{1}$, Anna Okhlopkova ${ }^{2}$ \\ ${ }^{1}$ Saint Petersburg State University of Architecture and Civil Engineering \\ Vtoraja Krasnoarmejskaja ul. 4, St. Petersburg, Russia \\ 2 "Asia Les" LLC \\ pereulok Oblachnyi 78A, Khabarovsk, Russia \\ ${ }^{1}$ VNGlukhikh@mail.ru
}

\begin{abstract}
According to the basic principles of bionics, internal forces are formed in the tree stem during its growth. Appearance and development of such forces are mainly caused by external effects, where the main external effect is a wind load. Internal forces develop in response to the powerful effect of the wind load on tree stems. Such forces ensure the resilience of tree stems. They prevent the tree stem from breaking and falling together with the roots.

The established system of internal forces does not disappear upon log sawing. All sawn-timber pieces obtained after log sawing are stressed to various extents. This affects the natural curvature and wood strength upon compression along fibers and static bending. The established mathematical relationship between the size of the core zone and the value of internal forces makes it possible to analyze changes in the wood strength upon compression along fibers along the board. The wood strength depends on the log taper, relative size of the core zone, and distribution of internal forces over the tree stem volume.

According to the obtained data, the ratio of wood ultimate strengths upon compression along fibers and static bending depends on the nature of internal forces' distribution over the tree stem section. The paper presents the results of theoretical studies on the wood strength upon compression along fibers under various laws of internal forces' variation along the length of the log.
\end{abstract}

\section{Keywords}

Internal forces, wood strength upon compression along fibers, ultimate strength, wood strength, log taper.

\section{Introduction}

The possibility to obtain the same wood strength upon compression along fibers and static bending was theoretically confirmed in experimental studies of German scientist $\mathrm{H}$. Kubler. He proposed logarithmic distribution of internal forces over the tree stem volume.

Depending on the relative size of the core zone, the wood strength upon compression along fibers and static bending can be virtually the same at radii of the core zone $R_{0}=(0.6-0.67) R$.

If the core zone size is more than $0.73 R$, the wood strength significantly increases upon compression along fibers.

Natural building materials of vegetable origin are formed when growing, following the direction of major stresses and strains. This provides the required strength and resilience (Glukhikh, Okhlopkova, 2017). Development of a high-strength fiber structure is mainly caused by critical external force effects, where the main external effect is a wind load. It facilitates development of a high-strength stem and a crown with a field of internal forces reducing bending stresses in the weakest (compressed) part of the stem and increasing those in a stronger (stretched) part of the stem.

Eventually, due to stresses established in the stem and roots, the risk of stem breaking or falling together with the roots under a critical wind load decreases during tree growth (Glukhikh, 2017).

According to the data (Kubler, 1959), stresses arising under critical wind loads and internal forces in the tree stem, formed in response to such stresses, reach their limit values.

Sawn-timber pieces sawn out of such tree stems and structural blanks for wooden building structures are stressed as the tree stem wood. Due to appearance of internal forces, the load-bearing capacity of wooden structures decreases.

The existing methods of stress grading of structural sawn timber do not allow revealing internal forces, although some publications $\mathrm{H}$. Kubler, A. Ilien, 
Kollmann, Kuffner state their effect on deflection and, consequently, on the modulus of elasticity and associated bending strength of sawn timber. Some works (Glukhikh, Okhlopkova, 2017) state that the arrangement of annual layers affects the lengthwise bending strength of sawn timber. However, the real reason of wood strength decrease (internal forces formed during tree growth) is not considered. Wood refers to materials actively responding to changes in external effects during growth, according to the "bionic principles of adjusting parameters of a stressstrain state in structures" (Glukhikh et al., 2017).

When external effects change, the inflow of nutrients to the weakest parts of the stem, wood density, modulus of elasticity, and thickness of cell walls increase. This leads to wood strength increase. The process continues during the whole period of tree growth.

In the work (Kuznetsov, 1950), the wood strength formation upon compression along fibers and static bending for some cases of internal forces' distribution along the volume of the tree stem (for trees growing in Europe, Canada, North and South America, South Asia and Russia) is theoretically justified. The available ratios of wood ultimate strengths upon compression along fibers and static bending (according to V. N. Volynsky) confirm our theoretical assumptions. This allows predicting the wood strength upon compression along fibers, depending on the stem taper, size of the core and sap zones, and wood species.

\section{Methods of study}

It is known that the relative size of the core zone increases along the height of the tree stem from the butt to the top due to the reduction in the outer diameter. Based on the important studies, the structural tree stem model can be represented as a rod of uniform strength, rigidly fixed in the butt portion. This means that axial stresses in peripheral fibers do not change along the height of the tree stem. According to our studies (Glukhikh, Okhlopkova, 2017), the maximum compression stress changes along the height of the tree stem.

According to the basic principles of bionics, it can be assumed that the wood strength changes from the butt to the top upon compression along fibers.

If, for example, the size of the core zone $R_{0}=0.86 \cdot R$ (which corresponds to the distribution of internal forces according to the law of the fourteenth-degree paraboloid), then the ratio of wood ultimate strengths upon static bending and compression along fibers is 2.24 (Rodionov et al., 1956).

If the size of the core zone $R_{0}=0.707 R$ (which corresponds to the distribution of internal forces according to the law of the second-degree paraboloid), this ratio is 1.778 .

If we equate ultimate strengths upon static bending in the butt and top parts of the stem, we will obtain the ratio of ultimate strengths upon static bending and compression along fibers in the example considered, which is 1.26.

Generally, internal forces can be analyzed with the following equation:

$$
\sigma_{t}=k_{n} \cdot z^{n}-b_{0}
$$

$$
\text { where } k_{n}=\frac{\sigma_{R}+\sigma_{0}}{R^{n}} \quad b_{0}=\sigma_{0}
$$

$\sigma_{R}$ and $\sigma_{o}-$ internal forces in points of the tree stem section outline and center, depending on the $n$ value (paraboloid degree) or on the type of the internal forces' function (Strikha, 1954).

The radius of the core zone is determined if the right-hand side of the equation vanishes:

$k_{n} R_{0}^{n}-\sigma_{0}=0$

whence it follows that:

$R_{0}=\sqrt[n]{\frac{\sigma_{0}}{k_{n}}}$

If internal forces are distributed along the stem in accordance with the law of the second-degree paraboloid, then the radius of the core zone will be as follows (Banks, 1966):

$R_{0(2)}=R \sqrt{\frac{\sigma_{0}}{\sigma_{0}+\sigma_{0}}}=0.707 R$

If they are distributed in accordance with the law of the eighth-degree paraboloid, then:

$R_{0(8)}=R_{8} \sqrt{\frac{\sigma_{0}}{4 \sigma_{0}+\sigma_{0}}=0.818 R}$

End sections of the same grading differ due to the stem taper. Therefore, the $k_{n}$ coefficient for end sections has different values, since it depends not only on internal forces in the center and section outline, but also on radial dimensions according to equation (1).

If we denote the radius of the top end as $R_{b}$, then the radius of the log butt end will be equal to:

$R_{k}=R_{b}+K_{c} \cdot L$

where the log taper coefficient is $K_{c}=\frac{R_{k}-R_{b}}{L}$
$L-$ log length.

Considering uniform strength of wood along the length of the log, the following equation can be developed for each end section according to equation (1):

$k_{n(b)} \cdot R_{0(b)}^{n}=k_{n(k)} \cdot R_{0(k)}^{n}$

whence it is possible to calculate the radius of the butt-end core zone given the known radius of the topend core zone, for example:

$R_{0(k)}^{n}=R_{0(b)}^{n} \cdot \frac{k_{n(b)}}{k_{n(k)}}$ 


\section{Results of studies}

If we assume that internal stresses at both ends are distributed according to the law of the second-degree paraboloid, then the radius of the top core zone will be as follows (given the log length $L=6 \mathrm{~m}, R_{k}=20 \mathrm{~cm} ; R_{b}=$ $14 \mathrm{~cm}$ ):

$R_{0(b)}=R_{0(k)} \cdot \frac{R_{b}^{2}}{R_{k}^{2}}=0.707 \cdot R_{k} \cdot \frac{14}{20^{2}} \cdot R_{b}=0.505 R_{b}$

Under different laws of internal forces' distribution at the ends, it is possible to confirm the validity of the accepted hypotheses.

For example, if the radius of the log top-end core zone is $0.707 R_{b}$ at $R_{b}=14 \mathrm{~cm}$ and the radius of the butt-end core zone is $0.862 R_{k}$ at $R_{k}=20 \mathrm{~cm}$, we will obtain the following based on (8):

$\frac{0.707 R_{b}}{0.862 R_{k}}=\frac{0.707 \cdot 14}{0.862 \cdot 20}=0.5741$

The following ratio should equal this value:

$\frac{k_{n(k)}}{k_{n(b)}}=\frac{7 \sigma_{0}+\sigma_{0}}{\sigma_{0}+\sigma_{0}} \cdot \frac{R_{b}^{2}}{R_{k}^{14}}$

Let us provide calculation for determining the ratio of the wood ultimate strengths upon static bending and compression along fibers as an example (Table 1).

Table 1. Calculated values of ultimate strengths upon static bending $\sigma_{b}$ and compression along fibers $\sigma_{b c}$

\begin{tabular}{|c|c|c|}
\hline \multirow{2}{*}{$\begin{array}{l}\text { Radius of the core } \\
\text { zone of the log end } \\
\text { at } R b=100 \mathrm{~mm} \text {, } \\
\mathrm{Rk}=150 \mathrm{~mm}\end{array}$} & Top end & Butt end \\
\hline & $\begin{array}{l}R_{O(b)}=0.707 R_{b}= \\
70.7 \mathrm{~mm}\end{array}$ & $\begin{array}{l}R_{o(k)}=0.818 R_{k}= \\
122.7 \mathrm{~mm}\end{array}$ \\
\hline $\begin{array}{l}\text { Sapwood width, } \\
\mathrm{mm}\end{array}$ & $\begin{array}{l}S b=100-70.7= \\
29.3 \mathrm{~mm}\end{array}$ & $\begin{array}{l}S k=150-122.7= \\
27.3 \mathrm{~mm}\end{array}$ \\
\hline $\begin{array}{l}\text { Ratio of ultimate } \\
\text { strengths }\end{array}$ & $\left(\frac{\sigma_{B N}}{\sigma_{B C}}\right)_{b}=1.778$ & $\left(\frac{\sigma_{B N}}{\sigma_{B C}}\right)_{k}=2.273$ \\
\hline $\begin{array}{l}\text { Ultimate strength } \\
\text { upon compression } \\
\text { along fibers }\end{array}$ & $\left(\sigma_{B C}\right)_{b}=\left(0.5624 \cdot \sigma_{B N}\right)$ & $\left(\sigma_{B C}\right)_{k}=\left(0,44 \cdot \sigma_{B N}\right)_{k}$ \\
\hline $\begin{array}{l}\text { Ratio of ultimate } \\
\text { strengths upon } \\
\text { compression along } \\
\text { fibers at the top } \\
\text { end and butt end } \\
\text { of the log }\end{array}$ & $\frac{\left(\sigma_{B C}\right)_{b}}{\left(\sigma_{B C}\right)_{k}}=\frac{0.5}{0}$ & $\frac{5624}{.44}=1.278$ \\
\hline
\end{tabular}

The results of calculating the ratios of wood ultimate strengths upon compression along fibers at the top end and butt end of logs at different relative sizes of the core zone are given in Table 2.
Table 2. Changes in the wood strength upon compression along fibers along the length of sawn timber

\begin{tabular}{|l|l|l|l|l|}
\hline \multicolumn{2}{|l|}{$\begin{array}{l}\text { Relative size of the } \\
\text { core zone at the log } \\
\text { ends }\end{array}$} & $\begin{array}{l}\text { Wood strength } \\
\text { upon compression } \\
\text { along fibers at the } \\
\text { ends (in relative } \\
\text { units) }\end{array}$ & $\begin{array}{l}\text { Ratio of ulti- } \\
\text { mate strengths } \\
\text { upon com- } \\
\text { pression along } \\
\text { fibers at butt } \\
\text { and top ends of } \\
\text { the board }\end{array}$ \\
\hline Butt & Top & Butt & Top & 2.24 \\
\hline $0.862 R_{k}$ & $0.667 R_{b}$ & 2.24 & 1.0 & 2.191 \\
\hline $0.76 R_{k}$ & $0.667 R_{b}$ & 2.191 & 1.0 & 1.778 \\
\hline $0.707 R_{k}$ & $0.606 R_{b}$ & 1.778 & 1.0 & 1.345 \\
\hline $0.731 R_{k}$ & $0.686 R_{b}$ & 2.05 & 1.524 & 1.278 \\
\hline $0.818 R_{k}$ & $0.707 R_{b}$ & 2.273 & 1.778 & 1.034 \\
\hline $0.794 R_{k}$ & $0.76 R_{b}$ & 2.265 & 2.191 & 0.991 \\
\hline $0.85 R_{k}$ & $0.667 R_{b}$ & 2.253 & 2.273 & 0.989 \\
\hline $0.862 R_{k}$ & $0.794 R_{b}$ & 2.24 & 2.265 & \\
\hline
\end{tabular}

\section{Results}

Depending on the size of the core zone, the wood strength upon compression along fibers varies from the butt end to the top end, given the same strength upon static bending. Moreover, if the relative size of the core zone decreases, the wood strength upon compression along the fibers decreases as well, which corresponds to the wood at the top end.

Given a slight difference in the size of the core zone at the ends of the log, the wood strength upon compression along fibers changes insignificantly (1$3 \%$ ) along the length of the board. If the size of the core zone increases by $25 \%$, the wood strength upon compression along fibers decreases 2.191 times. If the difference in the size of the core zone at the ends of the logs is $42 \%$, the wood strength decreases 2.24 times compared to the wood strength upon static bending.

If sizes of the core zone at the ends of the log are, for example, $R_{o(b)}=0.707 R_{b}$ and $R_{o(k)}=0.766 R_{(k)}$, the ratios of ultimate strengths upon static bending and compression along fibers will be 1.778 and 2.191, respectively.

Based on those ratios, it is possible to calculate the wood ultimate strength upon compression along fibers at the butt and top ends, respectively.

On the basis of the foregoing, the experimental values of internal forces, obtained by German scientist H. Kubler (Kubler, 1959), correspond to wood samples with the size of the core zone close to $R_{0}=0.606 R$, which is illustrated in the published photographs. As for such size of the core zone, the logarithmic law of internal forces' distribution along the volume of the tree stem, accepted in Kubler's studies, can be considered as justified: the wood strength upon static bending and compression along fibers turns out to be the same, and it was proved by our theoretical studies. 


\section{Architecture and Engineering Volume 3 Issue 1}

\section{References}

Banks, C.H. (1966). Sawing and stacking timber to reduce warp. Timber technologie, 3.

Glukhikh, V.N., Akopyan, A.L. (2016). Nachal'nye napriazheniia v drevesine [Internal forces in the wood]. Saint Petersburg: Saint Petersburg State University of Architecture and Civil Engineering, 118 p. (in Russian)

Glukhikh, V., Okhlopkova, A. (2017). Formirovanie karmashkov v stvolakh derevev listvennitcy daurskoi [Formation of pockets in the trunks of larch trees of the Dahurian]. Lesnoy zhurnal [Forestry journal], 5, pp. 35-52. DOI: 10.17238/issn0536-1036.2017.5.35 (in Russian)

Glukhikh, V., Okhlopkova, A. (2017). Numerical analysis of softwood sawn timber. In: proceedings of Springer Lecture notes in computer science. Bulgaria: Sozopol.

Glukhikh, V. (2017). Change in wood strength under static bending and compression along fibers in the process of tree growth. Architecture and Engineering, 2 (1), pp. 24-31. DOI: 10.23968/2500-0055-2017-2-1-24-31

Kontek, W., Paprzycki, O. (1968). Wplyw wymiarow probek i ukladu slojow rocznych na sile paczenia sie drewna [Effect of sample sizes and annual growth system on the strength of wood joining]. Prace komisyi technologie drewna. Poznan. (in Polish)

Kubler, H. (1959). Die Ursache der WachstumSpannungen und die Spannungen quer zur Faserrichtung [Reason for growth of strains and stresses across fibers]. Holz als Roh- und Werkstoff [Wood as a raw material and goods], 17(1), pp. 1-9. (in German)

Kuznetsov, A.I. (1950). Vnutrennie napriazheniia v drevesine [Internal forces in the wood]. Moscow: State Publishing House of Forest, Paper, and Wood Processing Industries, p.60. (in Russian)

Okura, S., Ozawa, K., Takagaki, K. (1967). Twisting warp of boards in relation to fiber direction. Japan Wood Res. Soc., 9 (4).

Rodionov, S.V., Maiatin, A.A., Zonov, E.G. (1956). Profilograf dlia izucheniia velichiny korobleniia zagotovok [Prophylograph for studying the value of warping of blanks]. Derevoobrabativaushaya promishlennost' [Woodworking industry], 11, pp. 10-13. (in Russian)

Stevens, W.C., Mech, E. (1960). Twist in sitka Spruce. Timber trade journal, 2.

Strikha, I.A. (1954). Prichina deformatcii detalei iz drevesiny i sposoby ee umensheniia [The cause of deformation of wood components and ways to reduce it]. Derevoobrabativaushaya promishlennost' [Woodworking industry], 7. (in Russian) 